\title{
Fermentation kinetics and ruminal parameters of animals fed diets containing Brazil nut cake inclusion levels
}

\author{
Cinética de fermentação e parâmetros ruminais de animais \\ alimentados com dietas contendo níveis de inclusão de torta da \\ amêndoa de castanha-do-pará
}

\author{
Juliana Cristina de Castro Bude ${ }^{1 *}$; Aline Fernanda de Oliveira Ramos ${ }^{1}$; \\ Geisielly Sousa Araújo ${ }^{1}$; Alyne Cristina Sodré Lima ${ }^{1}$; Lucieta Guerreiro \\ Martorano²; Benjamim de Souza Nahúm²; Luciano Fernandes Sousa ${ }^{3}$; \\ André Guimarães Maciel e Silva ${ }^{4}$; José de Brito Lourenço Junior ${ }^{5}$
}

\begin{abstract}
The inclusion effect of 0 (control), 15, 30, 45, 60, and 100\% dry matter (DM) of Brazil nut (Bertholletia excelsa Bonpl.) cake (BNC) aiming at replacing corn silage was assessed on fermentation kinetics and effective degradability (ED) by means of in vitro gas production at 3, 6, 9, 12, 24, 48, 72 and $96 \mathrm{~h}$. A randomized block design was used with six treatments, three blocks, and two replications per block. France's model was fit to the data. An in vivo experiment, conducted in fistulated ovine, assessed the effects of BNC inclusion levels of $0,15,30$, and $45 \%$ DM replacing corn silage on ruminal parameters. Ruminal fluid samples were collected postprandial at $8,10,12,14,16$, and $18 \mathrm{~h}$ for determining the concentrations of short-chain fatty acids (SCFA), $\mathrm{pH}$, and $\mathrm{N}-\mathrm{NH}_{3}$. A completely randomized design with repeated measures in time was used, with four treatments and three replications. Results of acetate, propionate, butyrate, acetate to propionate ratio, $\mathrm{pH}$, and $\mathrm{NH}_{3}$ were submitted to analysis of variance and regression (linear and quadratic) considering treatment, time and interaction of both. In addition, the $\mathrm{F}$ test with a $5 \%(\mathrm{P}<0.05)$ significance level was applied to the data. Fermentation kinetics pattern and ED presented a linear decreasing $(\mathrm{P}<0.05)$, which means a decrease in total gas production at each coproduct inclusion level. No interaction effect between treatment and time was observed for total SCFA $(\mathrm{P}>0.40)$, acetic acid $(\mathrm{P}>0.41)$, propionic acid $(\mathrm{P}>0.85)$, butyric acid $(\mathrm{P}>0.62)$ and $\mathrm{pH}(\mathrm{P}>0.57)$. BNC replacements of $0,15,30$ and $45 \%$ did not change $(\mathrm{P}>0.05)$ total SCFA concentration, as well as acetic acid concentration in ovine. When including $45 \% \mathrm{DM}$ of $\mathrm{BNC}$, concentrations $(\mathrm{mMol} / 100 \mathrm{~mL})$ of propionic $(\mathrm{P}<0.001)$ and butyric $(\mathrm{P}<0.022)$ acids was reduced in the ruminal fluid. The highest concentrations at measurement times were observed 4 hours after feeding. The $\mathrm{pH}$ values presented a quadratic effect on both inclusion $(\mathrm{P}<0.001)$ and time $(\mathrm{P}<0.001)$. An interaction was observed between treatment and time for $\mathrm{N}-\mathrm{NH}_{3}$ concentration $(\mathrm{mg} / \mathrm{ml})(\mathrm{P}<0.001)$ and acetic to propionic acids ratio $(\mathrm{P}<0.014)$. Fermentation kinetics was negatively affected by Brazil nut cake inclusion to corn silage-based diet. Therefore, the use of this coproduct is recommended associated with non-structural carbohydrate sources.
\end{abstract}

Key words: Amazon. Bertholletia excelsa. Coproduct. Ovine. Supplementation.

\footnotetext{
${ }^{1}$ Mestres em Ciência Animal, Universidade Federal do Pará, UFPA, Belém, PA, Brasil. E-mail: julianabudel@hotmail.com; ramos.afo@gmail.com; geisielly.sousa@hotmail.com; alynecsl@gmail.com

2 Pesquisadores, Empresa Brasileira de Pesquisa Agropecuária, Embrapa Amazônia Oriental, Belém, PA, Brasil. E-mail: benjamim. nahum@embrapa.br; lucieta.martorano@embrapa.br

3 Prof., Assistente, Universidade Federal do Tocantins, UFT, Araguaína, TO, Brasil. E-mail: luciano.sousa@uft.edu.br

${ }^{4}$ Prof., Assistente, UFPA, Belém, PA, Brasil. E-mail: andregms@gmail.com

5 Prof., Assistente, Programa de Pós-Graduação em Ciência Animal, UFPA, Belém, PA, Brasil. E-mail: joselourencojr@yahoo. com.br

* Author for correspondence
} 


\section{Resumo}

Avaliou-se o efeito da inclusão da torta da amêndoa de castanha-do-pará (Bertholletia excelsa Bonpl.) - (TAC) nas proporções 0 (controle), 15, 30, 45, 60 e 100\% da matéria seca (MS) em substituição à silagem de milho (SM), sobre a cinética de fermentação e a degradabilidade efetiva (DE), através da produção de gases in vitro, nos tempos 3, 6, 9, 12, 24, 48, 72 e 96 horas. Utilizou-se delineamento em blocos casualizado, com seis tratamentos, três blocos e duas repetições por bloco. O modelo de France foi ajustado aos dados. Ensaio in vivo, conduzido em ovinos fistulados, avaliou-se a influência da TAC nos níveis $0,15,30$ e 45\% (MS), em substituição à silagem de milho, sobre os parâmetros ruminais desses animais. As coletas de líquido ruminal para determinação da concentração dos Ácidos Graxos de Cadeia Curta (AGCC), $\mathrm{pH}$ e N-NH foram realizadas às $08 \mathrm{~h} 00,10 \mathrm{~h} 00,12 \mathrm{~h} 00,14 \mathrm{~h} 00,16 \mathrm{~h} 00$ e $18 \mathrm{~h} 00$, pós-prandial. Utilizou-se delineamento inteiramente casualizado, com medidas repetidas no tempo, sendo quatro tratamentos e três repetições. Os resultados das variáveis: acetato, propionato, butirato, relação acetato:propionato, $\mathrm{pH}$ e $\mathrm{NH}_{3}$ foram submetidos à análise de variância e regressão (linear e quadrática) considerando-se tratamento, tempo e a interação de ambos. Aplicou-se teste $\mathrm{F}$, com nível de significância de $5 \%(\mathrm{P}<0,05)$. O padrão de cinética de fermentação e $\mathrm{DE}$ foi linear decrescente $(\mathrm{P}<0,05)$, diminuiu a produção de gás total à cada nível de inclusão do coproduto. Não houve efeito da interação tratamento vs tempo para as variáveis AGCC total $(\mathrm{P}>0,40)$, ácido acético (P $>0,41)$, propiônico $(\mathrm{P}>0,85)$, butírico $(\mathrm{P}>0,62)$ e $\mathrm{pH}(\mathrm{P}>0,57)$. As substituições de TAC de 0,15 , 30 e $45 \%$ não alteraram $(P>0,05)$ a concentração de AGCC total, da mesma maneira, não modificou a concentração do ácido acético dos ovinos. Com inclusão de 45\% MS de TAC, a concentração dos ácidos propiônico e butírico $\mathrm{mMol} / 100 \mathrm{~mL}$ de líquido ruminal reduziram $(\mathrm{P}<0,001)$ e $(\mathrm{P}<0,022)$, respectivamente. As maiores concentrações, nos tempos de mensuração foram observadas 4 horas após a alimentação. Os valores de $\mathrm{pH}$ apresentaram efeito quadrático tanto na inclusão $(\mathrm{P}<0,001)$, quanto no tempo $(\mathrm{P}<0,001)$. Houve interação tratamento vs tempo na concentração de ${\mathrm{N}-\mathrm{NH}_{3}}_{3}(\mathrm{mg} / \mathrm{ml})(\mathrm{P}<$ $0,001)$ e na relação dos ácidos acético:propiônico $(\mathrm{P}<0,014)$. A cinética de fermentação foi afetada negativamente pela inclusão de torta da amêndoa da castanho-do-pará, à dieta à base de silagem de milho. Recomenda-se o uso desse coproduto, associado à fontes de carboidrato não estrutural.

Palavras-chave: Amazônia. Bertholletia excelsa. Coproduto. Ovinos. Suplementação.

\section{Introduction}

The increase of world population generates demand for food such as animal-origin products. This situation generates new possibilities of economic gain for productive sector, but reinforces the need for adjustments in production, making it increasingly sustainable (PAULA et al., 2014). However, in much of Brazil, performance, production cycles, and age of slaughter are compromised by forage seasonality, affecting economic and environmental sustainability (MORAES et al., 2010).

Attractive alternatives have been studied in recent years, including a proposal to supplement the deficiencies caused by forage with low nutritional value. Increasingly, agroindustrial coproducts have characteristics of replacing energy and/or protein concentrates that commonly compete with human nutrition, as well as subsidize the productive development of small and medium farmers, even in periods of low forage supply.

In the Amazon region, almost all Brazil nut (Bertholletia excelsa Bonpl.) is derived from extraction of forest peoples as a source of employment and income, aiming at their subsistence and sustainable use of local ecosystems. Oil properties of this nut have attracted attention and generated high demand nationally and internationally. Brazil nut cake (BNC) is a residue from oil extraction carried out by a mechanical press (SOUZA; MENEZES, 2004), being added rice husk in the process to potentiate oil removal, which makes it impossible using this coproduct in the food industry. However, it has a great potential for ruminant feeding use. Ramos et al. (2016) included BNC in ovine diet and observed that $56 \%$ inclusion is the maximum limit so that the ingestion behavior of dry matter (DM) of animals was not altered. 
Assessments performed by using in vitro techniques are among those that offer good correlations with the results found in vivo, quickness and cost reduction. Food quality can be inferred through fermentation kinetics. The parameters volatile fatty acids (VFA), $\mathrm{pH}$, and ammoniacal nitrogen $\left(\mathrm{N}-\mathrm{NH}_{3}\right)$ are considered as an indicative of reactions that occur from food ingestion. Interactions that occur when oilseed coproducts are included in animal diet have been supported by several studies (SANTOS et al., 2012; CHANJULA et al., 2011; WATANABE et al., 2010) and indicate that changes in patterns are dependent, among other factors, on quantity and quality of coproducts included in the diet.

Studies on BNC use as an alternative to ruminant feeding are scarce but necessary for being a viable option for small regional farmers. Thus, this study aimed to assess the fermentation kinetics and ruminal parameters of ovine fed diets containing Brazil nut cake inclusion levels.

\section{Materials and Methods}

\section{Fermentation kinetics}

The in vitro gas production experiment was performed at the Nutrition Laboratory of the Federal University of Minas Gerais (UFMG) located in Belo Horizonte, Minas Gerais, Brazil (1955'15” S and $\left.43^{\circ} 56^{\prime} 16^{\prime \prime} \mathrm{W}\right)$, where corn silage was replaced with $0,15,30,45,60$ and $100 \%$ BNC, based on dry matter. BNC was obtained by mechanical pressing and by using rice husk in the Amazon Oil agroindustry located in Ananindeua, Pará, Brazil.

The experimental design for gas production (in vitro study) was randomized block design with six treatments, three blocks, and two replications per block; the inocula collected from three bovines configured the blocks. Cumulative profiles of gases produced by in vitro fermentation were performed by a semi-automated technique as Theodorou et al. (1994), modified by Maurício et al. (1999).
Inocula were obtained from rumen-fistulated bovine maintained on pasture and supplemented with standard concentrate from the UFMG laboratory. The inoculum was mixed and filtered with cotton fabric layers and maintained in a water bath at $39{ }^{\circ} \mathrm{C}$ with carbon dioxide continuously insufflated for preparing $100 \mathrm{~mL}$ of buffered ruminal fluid (9:1 buffer to liquid ratio). The buffer solution was prepared according to Theodorou et al. (1994). Samples of $0.5 \mathrm{~g}$ were pre-dried in a forced ventilation oven at $65^{\circ} \mathrm{C}$ for 72 hours and ground in a 1-mm sieve mill.

Subsequently, mixture and samples were incubated in individual $160-\mathrm{mL}$ glass bottles previously identified with hard-to-remove paint, sealed with rubber stoppers, and maintained at $39{ }^{\circ} \mathrm{C}$, as Menke et al. (1979). Bottles with only buffered ruminal fluid were used as standards. Pressure readings were obtained by means of a pressure transducer at 3,6, 9, 12, 24, 48, 72, and $96 \mathrm{~h}$ after inoculation. Gas production at each time was corrected by subtracting the production in bottles with samples from the production obtained in bottles with only ruminal fluid (standard). Pressure was converted into gas volume using the equation $\mathrm{V}=-0.004$ (s.e. 0.06$)+4.43 \mathrm{P}$ (s.e. 0.043 ) $+0.051 \mathrm{P}^{2}$ (s.e. 0.007), previously obtained when the equipment was calibrated, as in Maurício et al. (2003).

\section{Ruminal parameters}

The in vivo experiment was approved by the Ethics Committee on Experimental Animal Research of the Federal University of Pará under the protocol BIO 120-13 and conducted at Embrapa Eastern Amazon, Animal Research Unit "Senador Álvaro Adolpho," Belém, Pará, Brazil (1²7’21" S and $\left.48^{\circ} 30^{\prime} 16^{\prime \prime} \mathrm{W}\right)$.

The experimental design was completely randomized design with repeated measures in time with four treatments and three replications. Variables were collected every 2 hours between 0 and $10 \mathrm{~h}$ 
postprandial. Twelve non-defined-breed rumenfistulated ovines, with an average weight of $35 \mathrm{~kg}$, were maintained in individual metabolic cages in a closed shed and fed twice a day at 8 and $18 \mathrm{~h}$, allowing $10 \%$ leftovers from that was supplied, in addition to water ad libitum.

Ovine underwent adaptation for 21 days to diets with corn silage replacement by Brazil nut cake at levels of $0,15,30,45,60$, and 100\% (DM). On the 22nd day, representative portions of ruminal contents were collected and filtered in double cotton fabric to extract the rumen fluid at 0 (before feeding), 2, 4, 6, 8 and $10 \mathrm{~h}$ postprandial. The $\mathrm{pH}$ admeasurement was performed at collection time by using a portable digital $\mathrm{pH}$ meter (MB-10, Marte, Sapucaí, Brazil). Subsequently, this material was stored in identified bottles and maintained in a freezer for other analyses.

Concentrations of short-chain fatty acids (SCFA) were determined by gas chromatography by using aliquots of $8 \mathrm{~mL}$ and $1 \mathrm{~mL}$ meta-phosphoric acid solution addition (AZEVEDO, 1998). In order to assess the ammoniacal nitrogen $\left(\mathrm{N}-\mathrm{NH}_{3}\right)$ concentration in the ovine ruminal fluid, distillation and titration were performed as described by Fenner (1965), adapted by Vieira (1980). Aliquots of $80 \mathrm{ml}$ were collected from each collection, adding $1 \mathrm{~mL}$ sulfuric acid $\left(\mathrm{H}_{2} \mathrm{SO}_{4} 1: 1\right)$.

\section{Chemical analyses}

The chemical composition of diet ingredients was determined at the Nutrition Laboratory of the Federal University of Pará, Castanhal campus, Pará, Brazil (1 ${ }^{\circ} 17^{\prime} 38^{\prime \prime} \mathrm{S}$ and $\left.47^{\circ} 55^{\prime} 35^{\prime \prime} \mathrm{W}\right)$. In pre-dried samples, contents of dry matter (DM), organic matter (OM), mineral matter (MM) and crude protein $(\mathrm{PB})$ were determined according to AOAC International (AOAC, 2005) procedures. Neutral detergent fiber (NDF), acid detergent fiber (ADF), cellulose (CEL), hemicellulose (HEMI) and lignin (LIG) were determined by the sequential method of Van Soest et al. (1991). In addition, ethereal extract (EE) was determined by the method described by Silva and Queiroz (2002). In all analyses, INCT recommendations in Detmann et al. (2012) were followed. Table 1 presents bromatological composition percentage of experimental diets.

Table 1. Bromatological composition of experimental diets.

\begin{tabular}{lcccccc}
\hline \multirow{2}{*}{ Variable (DM, \%) } & \multicolumn{7}{c}{ BNC $^{1}$ inclusion (\%) } \\
\cline { 2 - 7 } & 0 & 15 & 30 & 45 & 60 & 100 \\
\hline Dry matter & 33.07 & 40.98 & 48.90 & 56.82 & 64.73 & 85.85 \\
Organic matter & 95.21 & 94.35 & 93.49 & 92.63 & 91.77 & 89.48 \\
Mineral matter & 4.79 & 5.65 & 6.50 & 7.36 & 8.22 & 10.52 \\
Neutral detergent insoluble ash & 1.05 & 1.17 & 1.30 & 1.43 & 1.56 & 1.90 \\
Acid detergent insoluble ash & 0.76 & 0.80 & 0.84 & 0.89 & 0.93 & 0.10 \\
Crude protein & 7.88 & 11.95 & 16.02 & 20.09 & 24.17 & 35.03 \\
Neutral detergent insoluble protein & 0.71 & 2.10 & 3.49 & 4.88 & 6.27 & 9.99 \\
Acid detergent insoluble protein & 0.24 & 0.63 & 1.02 & 1.41 & 1.80 & 2.85 \\
Ethereal extract & 4.38 & 5.97 & 7.56 & 9.15 & 10.75 & 15.00 \\
Neutral detergent insoluble fiber ap ${ }^{2}$ & 38.21 & 37.06 & 35.90 & 34.75 & 33.60 & 30.54 \\
Acid detergent insoluble fiber & 19.25 & 18.61 & 17.97 & 17.33 & 16.70 & 15.00 \\
Lignin & 2.18 & 2.47 & 2.76 & 3.05 & 3.35 & 4.13 \\
Hemicellulose & 18.96 & 18.44 & 17.93 & 17.42 & 16.90 & 15.54 \\
Cellulose & 17.07 & 16.14 & 15.21 & 14.28 & 13.35 & 10.87 \\
Non-fibrous carbohydrates & 44.74 & 39.36 & 33.99 & 28.61 & 23.24 & 8.91 \\
\hline BNC Bryyyyyyy
\end{tabular}

$\mathrm{BNC}^{1}$ : Brazil nut cake; ap ${ }^{2}$ : corrected for ashes and protein. 


\section{Statistical analyses}

Data normality was verified by the Shapiro-Wilk test and homogeneity of variances by the Bartlett and Cochran test. In order to estimate the in vitro ruminal fermentation kinetic parameters of each treatment, France and Siddons (1993) model was fitted to the data, as expressed in $\mathrm{Y}=\mathrm{A} \times\left\{1-\exp ^{[-\mathrm{b}}\right.$ $\left.\left.\times(t \times T)-c \times\left(V_{t}-\sqrt{T}\right)\right]\right\}$, where $Y$ is the accumulated gas production $(\mathrm{mL}), \mathrm{A}$ is the total gas produced $(\mathrm{mL}), \mathrm{t}$ is the incubation time (h), $\mathrm{T}$ is the colonization time (h), and $b^{(h-1)}$ and $c^{(h-0.5)}$ is the average fractional degradation rate $\mu\left(\mathrm{h}^{-1}\right)$, calculated as $\mu=\mathrm{b}+\mathrm{c} / 2 \sqrt{\mathrm{t}}$. Equations generated were compared by parallelism and curve identity tests $(\mathrm{P}<0.05)$, according to Regazzi and Silva (2004).

Effective degradability was estimated through $\mathrm{ED}=\mathrm{S}_{0} \times \operatorname{Exp}^{-\mathrm{kt}} \times(1-\mathrm{k}) /\left(\mathrm{S}_{0}+\mathrm{U}_{0}\right)$, where ED is the effective degradability, $\mathrm{k}=$ passage rate, calculated for $\mathrm{k}=2,5$, and $8 \% \mathrm{~h}^{-1}$, which means a low, medium, and high intake, respectively, according to the recommendations of the Report... (1984), and $\mathrm{S}_{0}$ and $\mathrm{U}_{0}$ are the initially fermentable fractions and non-fermentable fractions, respectively (FRANCE; SIDDONS, 1993).
For the in vivo experiment, results of concentrations of acetate, propionate, butyrate, acetate to propionate ratio, $\mathrm{pH}$, and $\mathrm{NH}_{3}$ from ovine ruminal fluid were submitted to analysis of variance and regression (linear and quadratic) considering treatment, time and interaction of both. The $\mathrm{F}$ test was used with a 5\% significance level.

\section{Results and Discussion}

\section{Fermentation kinetics}

Among the assessed parameters, the maximum potential ofgasproduction(A), fractionaldegradation rate $(\mu)$ and effective degradability of DM (EDDM) were numerically higher at $0 \%$ inclusion level (only corn silage), in addition to being found in the same treatment lower colonization time $(\mathrm{T})$. The opposite was observed as BNC was included in the diet (Table 2) since EDDM presented reduced values. Similarly, the higher the passage rates were, the lower the observed EDDM $\left(2<5<8 \% \mathrm{~h}^{-1}\right.$, i.e. low, medium and high intake, respectively).

Table 2. In vitro fermentation kinetics parameters of diets containing BNC inclusion levels, from France model and effective degradability of DM (EDDM) obtained for passage rates of 2,5 , and $8 \% \mathrm{~h}^{-1}$.

\begin{tabular}{lcccccc}
\hline \multirow{2}{*}{ France parameter } & \multicolumn{7}{c}{ BNC $^{1}$ inclusion } \\
\cline { 2 - 7 } & 0 & 15 & 30 & 45 & 60 & 100 \\
\hline $\mathrm{A}^{2}$ & 194.6047 & 188.9308 & 180.7920 & 182.5716 & 169.4461 & 141.1446 \\
$\mathrm{~T}^{3}$ & $00: 30: 47$ & $00: 32: 21$ & $00: 32: 43$ & $00: 44: 33$ & $00: 49: 15$ & $02: 32: 52$ \\
$\mu^{4}$ & 0.0586 & 0.0595 & 0.0615 & 0.0624 & 0.0625 & 0.0636 \\
$\operatorname{EDDM}(2 \%)$ & 52.2302 & 50.5915 & 50.5178 & 49.9181 & 49.4170 & 46.9138 \\
$\operatorname{EDDM}(5 \%)$ & 49.9791 & 48.3713 & 48.3009 & 47.4489 & 46.8574 & 42.2427 \\
$\operatorname{EDDM}(8 \%)$ & 47.7845 & 46.2094 & 46.1427 & 45.0643 & 44.3931 & 38.0050 \\
\hline
\end{tabular}

$\mathrm{BNC}^{1}$ : Brazil nut cake; $\mathrm{A}^{2}$ : total gas produced $(\mathrm{mL}) ; \mathrm{T}^{3}$ : colonization time (hours: minutes); $\mu^{4}$ : fractional degradation rate $\left(\mathrm{h}^{-1}\right)$.

Gas production is directly proportional to food microbial fermentation and allows assessing the way the microbial attack occurs during food degradation in the rumen (NEIVA JÚNIOR et al., 2010). Microorganisms can more or less easily degrade fractions that constitute a food. Non- fibrous carbohydrates (NFC), for example, present little in BNC (8.91\% DM), are important chemical constituents since they represent sources of fast energy availability, which implies in the initial growth of ruminal microorganisms (MIZUBUTI et al., 2011). 
The highest colonization time with $100 \% \mathrm{BNC}$ ( 2 h $32 \mathrm{~min}$ ) (Table 2) may have been a result of high levels of EE (15\% DM), which probably made it difficult to attack the diet fiber, higher amount of indigestible components, especially lignin $(4.13 \%$ $\mathrm{DM})$, and, especially, NFC reduction (8.91\% DM). An identical colonization time was found in a study that assessed fermentation kinetics of dry tamarind cake under $1.35 \mathrm{rpm}$, presenting 15\% EE and 33.7\% FNC (WANG et al., 2016). A colonization time of $5 \mathrm{~h}$ and 40 min was found in a study in which the babassu mesocarp flour was studied (SOUSA et al., 2014), which gives a higher nutritive value to $\mathrm{BNC}$ when compared to babassu flour.

EDDM can be considered as the energy digested in the rumen. For this reason, the highest EDDM values are in accordance with the maximum potential of gas production data. Food particle size and its flow through rumen directly influence the ruminant's digestive processes. Jobim et al. (2011) found EDDM values of corn silage by means of an in situ technique that corresponded to 47.34 $\left(5 \% \mathrm{~h}^{-1}\right)$ and $41.99\left(8 \% \mathrm{~h}^{-1}\right)$, which are lower than those determined for the same passage rates in this study (49.97 and 47.78). On the contrary, Pôssas et al. (2015) assessed the in vitro silage EDDM from three corn hybrids and found that even the lowest values cited were higher (67.04 and 62.56 for passage rates of 2 and $5 \% \mathrm{~h}^{-1}$ ) than those found here. In either case, those results are due to NDF and cellulose contents of silages, which were lower in the first study and higher in the second when compared to this study. Wang et al. (2016) observed EDDM values of 73.8 and 64.1 for passage rates of 2 and 5\% in an in situ assessment of tamarind cake.

Equations and curves related to regression analysis of ruminal fermentation kinetic data of diets (Table 3) presented gas production curves parallel to each other, with no statistical difference. However, by the curve identity test, a statistical difference was observed between equations of each inclusion level; all of them were different from each other, except for BNC inclusion levels of 15,30 , and $45 \%$, which did not differ from each other.

Table 3. Cumulative gas production (CGP) equations ( $\left.\mathrm{mL} \mathrm{g}^{-1} \mathrm{DM}\right)$ in diets with Brazil nut cake inclusion.

\begin{tabular}{ccc}
\hline Inclusion & Equation (France model) & $\mathrm{R}^{2}$ \\
\cline { 2 - 3 } 0 & $\hat{\mathrm{Y}}=194.6047 \times\{1-\exp [-(0.0777) \times(\mathrm{t} \times 0.5123)-(-0.1517) \times(\sqrt{ } \mathrm{t}-\sqrt{ } 0.5123)]\}$ a A & 99.78 \\
15 & $\hat{\mathrm{Y}}=127.3000 \times\{1-\exp [-(0.0774) \times(\mathrm{t} \times 0.5393)-(-0.1391) \times(\sqrt{\mathrm{t}}-\sqrt{0.5393})]\}$ a B & 99.49 \\
30 & $\hat{\mathrm{Y}}=124.5000 \times\{1-\exp [-(0.0835) \times(\mathrm{t} \times 0.5453)-(-0.1765) \times(\sqrt{\mathrm{t}}-\sqrt{ } 0.5453)]\}$ a B & 99.42 \\
45 & $\hat{\mathrm{Y}}=125.4000 \times\{1-\exp [-(0.0858) \times(\mathrm{t} \times 0.7427)-(-0.1891) \times(\sqrt{\mathrm{t}}-\sqrt{0.7427})]\}$ a B & 99.62 \\
60 & $\hat{\mathrm{Y}}=115.3000 \times\{1-\exp [-(0.0822) \times(\mathrm{t} \times 0.8210)-(-0.1523) \times(\sqrt{\mathrm{t}}-\sqrt{0} 0.8210)]\}$ a C & 99.84 \\
100 & $\hat{\mathrm{Y}}=96.3458 \times\{1-\exp [-(0.0861) \times(\mathrm{t} \times 2.5480)-(-0.1773) \times(\sqrt{\mathrm{t}}-\sqrt{2} .5480)]\}$ a D & 99.56 \\
\hline
\end{tabular}

$\mathrm{R}^{2}$ : coefficient of determination (\%). Equations followed by equal lowercase letters in the same column are parallel by the curve parallelism test at 5\% probability. Equations followed by equal uppercase letters in the same column are identical by the curve identity test at $5 \%$ probability (REGAZZI; SILVA, 2004).

The differences $(\mathrm{P}<0.05)$ observed in the curve identity test (Table 3), more specifically for inclusion levels from 0 to $15 \%$ and from 45 to $60 \%$ $\mathrm{BNC}$, can be compared and explained by two events observed in an in vivo experiment conducted by Ramos (2014): fiber digestibility affected by a $16 \%$ $\mathrm{BNC}$ inclusion, which corresponds to $6 \% \mathrm{EE}$ in the diet; and DM consumption affected by a $58.4 \%$ $\mathrm{BNC}$ inclusion.

\section{Ruminal parameters}

No interaction effect between treatment and time was observed for total SCFA, acetic acid, propionic acid, butyric acid and $\mathrm{pH}$. No effect was also observed in the concentrations of total SCFA and total acetic acid among treatments. From $\mathrm{BNC}$ inclusion to the diet, a decrease in propionic acid concentration was observed; for butyric acid 
concentration, on the other hand, a quadratic effect was observed, with higher concentrations for 15 and 30\% BNC inclusions and lower in 45\% DM. The $\mathrm{pH}$ showed a quadratic effect and an inverse tendency to that observed for SCFA; with higher values in the diet with $45 \%$ BNC inclusion and lower values when $18 \%$, DM of $\mathrm{BNC}$ was added to the diet (Table 4).

Table 4. Short-chain fatty acids concentration ( $\mathrm{mMol} 100 \mathrm{~mL}^{-1}$ ruminal fluid) and average $\mathrm{pH}$ values of ruminal fluid of ovine fed Brazil nut cake increasing levels in replacement to corn silage.

\begin{tabular}{|c|c|c|c|c|c|c|c|c|}
\hline \multirow{2}{*}{ Item } & \multicolumn{4}{|c|}{ BNC inclusion (\%) } & \multirow{2}{*}{ Regression } & \multirow{2}{*}{$\mathrm{R}^{2}$} & \multirow{2}{*}{ P-value } & \multirow{2}{*}{$\mathrm{CV}$} \\
\hline & 0 & 15 & 30 & 45 & & & & \\
\hline $\mathrm{SCFA}^{1}$ & 56.66 & 52.77 & 50.55 & 46.66 & $\hat{Y}=56.50$ & - & 1.000 & 54.20 \\
\hline $\mathrm{AA}^{3}$ & 38.41 & 33.79 & 32.38 & 32.70 & $\hat{Y}=38.34$ & - & 0.141 & 21.88 \\
\hline $\mathrm{PA}^{4}$ & 14.99 & 14.43 & 14.13 & 12.68 & $\hat{Y}=15.14-0.004 x$ & 89.83 & $<0.001$ & 8.39 \\
\hline $\mathrm{BA}^{5}$ & 3.75 & 3.98 & 3.98 & 3.19 & $\hat{Y}=3.72+0.004 x-0.0001 x^{2}$ & 95.97 & 0.022 & 24.28 \\
\hline $\mathrm{pH}$ & 6.56 & 6.45 & 6.41 & 6.65 & $\hat{Y}=6.57-0.015 x+0.0004 x^{2}$ & 93.11 & 0.001 & 2.67 \\
\hline
\end{tabular}

SCFA $^{1}$ : total short-chain fatty acids; $\mathrm{R}^{2}$ : coefficient of determination (\%); $\mathrm{AA}^{3}$ : acetic acid; $\mathrm{PA}^{4}$ : propionic acid; $\mathrm{BA}^{5}$ : butyric acid; $\mathrm{CV}$ : coefficient of variation (\%).

Decreasing NDF digestibility, caused by EE excess in the diet (RAMOS, 2014), was probably the main factor in reducing propionic and butyric acids concentration. Similar conditions were observed when assessing 30\% rubber tree cake $+30 \%$ palm cake inclusion (CHANJULA et al., 2011). Recent studies have demonstrated unsatisfactory effects due to fiber digestion reduction caused by high oil concentrations in ruminant diets (PATRA, 2014; SANTOS et al., 2016).

Values of $\mathrm{pH}$ at all inclusion levels remained within the range considered as appropriate (6.0 to 7.0) to occur fiber and protein digestion (HOOVER, 1986; VAN SOEST, 1994) and may have been higher in the diet with $45 \%$ BNC (6.65) due to fermentation decreasing in diet compounds, limited amount of non-fibrous carbohydrates, and lignin and ethereal extract content increasing. Nutritional factors such as fiber and carbohydrate contents in the diet are the main influencers of ruminal $\mathrm{pH}$ since rumination time variation and fermentation products, such as volatile fatty acids (ALVES et al., 2012), may influence them.

Total and individual SCFA concentrations and $\mathrm{pH}$ values of ruminal fluid at measurement time presented quadratic effects. SCFA concentrations showed peaks at $4 \mathrm{~h} 25 \mathrm{~min}$ (acetic acid), $4 \mathrm{~h} 83 \mathrm{~min}$ (propionic acid) and $5 \mathrm{~h} 62 \mathrm{~min}$ (butyric acid) after feeding, and decrease henceforth. Ruminal fluid $\mathrm{pH}$ decreased from diet supply (after $0 \mathrm{~h}$ ) and increased gradually over time (Table 5).

Table 5. Short-chain fatty acids concentration (mMol $100 \mathrm{~mL}^{-1}$ ruminal fluid) and average $\mathrm{pH}$ values of ruminal fluid of ovine between 0 and $10 \mathrm{~h}$ postprandial.

\begin{tabular}{lccccccccccc}
\hline \multirow{2}{*}{ Item } & \multicolumn{6}{c}{ SCFA concentration between $0^{1}$ and $10 \mathrm{~h}$} & \multirow{2}{*}{ Regression } & \multirow{2}{*}{$\mathrm{R}^{2}$} & \multirow{2}{*}{ P-value } & \multirow{2}{*}{$\mathrm{CV}$} \\
\cline { 2 - 8 } & 8 & 10 & 12 & 14 & 16 & 18 & & & & \\
\hline SCFA & 44.16 & 62.50 & 63.33 & 45.83 & 50.83 & 43.33 & $\hat{\mathrm{Y}}=49.01+0.421 \mathrm{x}-0.050 \mathrm{x}^{2}$ & 47.49 & 0.001 & 20.54 \\
$\mathrm{AA}^{3}$ & 30.05 & 40.28 & 40.76 & 31.32 & 34.43 & 29.09 & $\hat{\mathrm{Y}}=32.59+0.255 \mathrm{x}-0.030 \mathrm{x}^{2}$ & 52.03 & 0.002 & 22.44 \\
$\mathrm{PA}^{4}$ & 10.42 & 17.67 & 18.25 & 12.59 & 13.45 & 11.97 & $\hat{\mathrm{Y}}=12.28+0.174 \mathrm{x}-0.018 \mathrm{x}^{2}$ & 45.56 & $<0.001$ & 24.6 \\
$\mathrm{BA}^{5}$ & 2.73 & 4.55 & 4.71 & 3.35 & 3.75 & 3.26 & $\hat{\mathrm{Y}}=3.18+0.045 \mathrm{x}-0.004 \mathrm{x}^{2}$ & 45.36 & 0.001 & 29.45 \\
$\mathrm{pH}$ & 6.79 & 6.21 & 6.43 & 6.5 & 6.54 & 6.63 & $\hat{\mathrm{Y}}=6.66-0.114 \mathrm{x}+0.011 \mathrm{x}^{2}$ & 43.96 & $<0.001$ & 2.95 \\
\hline
\end{tabular}

$0^{1}$ : SCFA concentration before first feeding; $\mathrm{R}^{2}$ : coefficient of determination (\%); SCFA: total short-chain fatty acids; $\mathrm{AA}^{3}$ : acetic acid; $\mathrm{PA}^{4}$ propionic acid; $\mathrm{BA}^{5}$ : butyric acid; $\mathrm{CV}$ : coefficient of variation (\%). 
When assessed in relation to time after feeding, the lowest $\mathrm{pH}$ value (6.21) of ruminal fluid, observed two hours postprandial, may be due to the fermentative effect of food offered, with a tendency to increase up to $10 \mathrm{~h}$ of measurements, when fermentation product concentrations are lower. Mesacasa et al. (2015) did not observe a significant difference in $\mathrm{pH}$ values of ruminal fluid after feeding ruminants with sunflower cake.
The average values observed from the interaction between treatment and time for ammoniacal nitrogen $\left(\mathrm{N}-\mathrm{NH}_{3}\right)$ of ruminal fluid are shown in Table 6. At all inclusion levels, $\mathrm{N}-\mathrm{NH}_{3}$ concentrations in ruminal fluid were higher two hours after feeding and, from this time on, a decrease was observed for this variable.

Table 6. $\mathrm{N}-\mathrm{NH}_{3}$ concentration $\left(\mathrm{mg} \mathrm{dl}^{-1}\right)$ in the rumen of ovine fed Brazil nut cake increasing levels (\%) between 0 and $10 \mathrm{~h}$ postprandial in replacement to corn silage.

\begin{tabular}{|c|c|c|c|c|c|c|c|c|c|c|}
\hline \multirow{2}{*}{ Inc. } & \multicolumn{6}{|c|}{ SCFA concentration between $0^{1}$ and $10 \mathrm{~h}$} & \multirow{2}{*}{ Regression } & \multirow{2}{*}{$\mathrm{R}^{2}$} & \multirow{2}{*}{ P-value } & \multirow{2}{*}{$\mathrm{CV}$} \\
\hline & 8 & 10 & 12 & 14 & 16 & 18 & & & & \\
\hline $0^{3}$ & 5.92 & 13.38 & 6.28 & 3.58 & 3.72 & 3.4 & $\hat{Y}=9.215-0.632 x$ & 38.74 & $<0.001$ & \multirow{4}{*}{22.21} \\
\hline 15 & 8.45 & 15.88 & 9.12 & 6.36 & 7.71 & 7.48 & $\hat{Y}=11.464-0.458 x$ & 25.21 & 0.001 & \\
\hline 30 & 7.10 & 20.34 & 17.99 & 15.35 & 13.44 & 12.44 & $\hat{Y}=10.073+3.147 x-0.309 x^{2}$ & 53.73 & $<0.001$ & \\
\hline 45 & 11.62 & 22.16 & 10.18 & 11.30 & 8.48 & 8.54 & $\hat{Y}=16.000-0.790 x$ & 33.25 & 0.001 & \\
\hline
\end{tabular}

Inc.: inclusion; $0^{1}$ : $\mathrm{N}-\mathrm{NH}_{3}$ concentration before first feeding; $\mathrm{R}^{2}$ : coefficient of determination (\%); $\mathrm{CV}$ : coefficient of variation (\%).

When evaluating BNC inclusion levels and time after supplementation, the average $\mathrm{N}-\mathrm{NH}_{3}$ concentrations $\left(\mathrm{mg} \mathrm{mL}^{-1}\right)$ in rumen fluid were in accordance with the minimum amount established for microbial growth, i.e. $5 \mathrm{mg} \mathrm{N} 100 \mathrm{~mL}^{-1}$ of ruminal fluid (SATTER, SLYTER, 1974), except for 0\% BNC diet between times 6 and 10. This fact can be explained by the lower crude protein percentage in the silage (7.88) when compared to other treatments. Two hours after supplementation, considering all inclusion levels, a $\mathrm{N}-\mathrm{NH}_{3}$ concentration peak occurred in the rumen, especially for 30 and $45 \%$ $\mathrm{BNC}$ diets, which presented averages closer to those proposed by Mehrez et al. (1977), so that maximum ruminal fermentation activity occurs (19 to $23 \mathrm{mg} \mathrm{Dl}^{-1}$ ). However, decreases were observed when comparing $\mathrm{N}-\mathrm{NH}_{3}$ concentrations in 30 and $45 \% \mathrm{BNC}$ diets during collection time, indicating that $30 \% \mathrm{BNC}$ inclusion in the diet would provide, for a longer time, a greater ammonia availability for microbial protein synthesis. Nitrogen supply increases fiber digestion by improving microbial efficiency from substrate addition to ruminal flora
(LIMA et al., 2013). Mesacasa et al. (2015) observed lower $\mathrm{N}-\mathrm{NH}_{3}$ concentrations in the ruminal fluid by including sunflower cake in the diet, which is due to the highest coproduct indigestible fraction.

The interaction between time and treatment of acetic to propionic acids ratio $(\mathrm{P}<0.014)$ (Table 7), showed a quadratic effect in the diets with 0 and $30 \% \mathrm{BNC}$, but a decrease was observed in this relation with $\mathrm{BNC}$ inclusion. The lowest values were observed for these treatments two and four hours after feeding, respectively. An ethereal extract content higher in the diet containing 30\% BNC possibly explains the acetic to propionic acids molar ratio, which decreased with $\mathrm{BNC}$ inclusion in the diet. Pimentel et al. (2012) observed that the acetate to propionate ratio was not affected by cashew nuts addition to the diet and Vargas et al. (2002) observed a decrease in acetate to propionate ratio of 3.09:2.93, suggesting that unsaturated lipid supply (ground soybean grain and soybean oil) inhibited gram-positive ruminal bacteria and stimulated those that produce propionate. 
Table 7. Acetic to propionic acids mole ratio in the rumen of ovine fed Brazil nut cake increasing levels (\% DM) at different time after supplementation.

\begin{tabular}{|c|c|c|c|c|c|c|c|c|c|c|}
\hline \multirow{2}{*}{ Inc. } & \multicolumn{6}{|c|}{ Acetic to propionic acids ratio between $0^{1}$ and $10 \mathrm{~h}$} & \multirow{2}{*}{ Regression } & \multirow{2}{*}{$\mathrm{R}^{2}$} & \multirow{2}{*}{ P-value } & \multirow{2}{*}{$\mathrm{CV}$} \\
\hline & 8 & 10 & 12 & 14 & 16 & 18 & & & & \\
\hline 0 & 3.33 & 2.33 & 2.33 & 2.67 & 3.00 & 3.33 & $\hat{Y}=3.142-0.323 x+0.035 x^{2}$ & 79.55 & $<0.001$ & \multirow{4}{*}{10.16} \\
\hline 15 & 2.67 & 2.33 & 2.00 & 2.33 & 2.67 & 2.00 & $\hat{Y}=2.535$ & - & 0.469 & \\
\hline 30 & 3.00 & 2.00 & 2.00 & 2.33 & 2.33 & 2.33 & $\hat{Y}=2.773-0.251 x+0.022 x^{2}$ & 53.21 & 0.001 & \\
\hline 45 & 3.00 & 2.33 & 2.33 & 3.00 & 2.67 & 2.33 & $\hat{\mathrm{Y}}=2.750$ & - & 0.808 & \\
\hline
\end{tabular}

Inc.: inclusion; $0^{1}$ : acetic to propionic acids ratio before first feeding; $\mathrm{R}^{2}$ : coefficient of determination (\%); $\mathrm{CV}$ : coefficient of variation (\%); NS: not significant.

\section{Conclusion}

Fermentation kinetics was negatively affected by Brazil nut cake inclusion to corn silage diet. Regarding ruminal parameters, propionic and butyric acids decreased from 30\% Brazil nut cake inclusion, but within that considered acceptable to ovine physiology. The use of this coproduct is recommended associated with non-structural carbohydrate sources.

\section{Acknowledgements}

To the Project Pecus/Bioma Amazônia for the financial support, to Embrapa Eastern Amazon, Federal University of Minas Gerais (UFMG) and Federal University of Pará (UFPA) for the laboratory support, and to Coordination for the Improvement of Higher Education Personnel (CAPES) for granting the scholarships.

\section{References}

ALVES, E. M.; PEDREIRA, M. S.; PEREIRA, M. L. A.; ALMEIDA, P. J. P.; GONSALVES NETO, J. FREIRE, L. D. R. Farelo da vagem de algaroba associado a níveis de ureia na alimentação de ovinos: balanço de nitrogênio, N-ureico no plasma e parâmetros ruminais. Acta Scientiarum, Maringá, v. 34, n. 3, p. 287-295, 2012.

ASSOCIATION OF OFFICIAL ANALYTICAL CHEMISTS - AOAC. Official methods of analysis of AOAC International. 18 ${ }^{\text {th }}$ ed. Gaithersburg: AOAC, 2005.

AZEVEDO, P. S. A casca do grão de soja em substituição ao feno de gramínea nas rações com diferentes fontes proteicas para bovinos. 1998. Dissertação (Mestrado em Zootecnia) - Faculdade de Ciências Agrárias e Veterinárias. Universidade Estadual Paulista, Jaboticabal.

CHANJULA, P.; SIRIWATHANANUKUL, Y.; LAWPETCHARA, A. Effect of feeding rubber seed kernel and palm kernel cake in combination on nutrient utilization, rumen fermentation characteristics, and microbial populations in Goats fed on briachiaria humidicola hay-based diets. Asian Australasian Journal of Animal Sciences, Songkla, v. 24, n. 1, p. 73-81, 2011.

DETMANN, E.; SOUSA, M. A.; VALADARES FILHO, S. C. Métodos para análise de alimentos. Visconde do Rio Branco: Suprema, 2012. 214 p.

FENNER, H. Methods for determining total volatile bases in rumen fluid by steam distillation. Journal of Dairy Science, Champaign, v. 48, n. 2, p. 249-251, 1965.

FRANCE, J.; SIDDONS, R. C. Quantitative aspects of ruminal digestion and metabolism. Cambridge: University Press, 1993. 215 p.

HOOVER, W. H. Chemical factors involved in ruminal fiber digestion. Journal of Dairy Science, Champaign, v. 69, n. 10, p. 2755-2766, 1986.

JOBIM, C. C.; FERREIRA, G. A.; BUMBIERIS JUNIOR, V.; CALIXTO JUNIOR, M.; SANTOS, G. T. Cinética de degradação ruminal dos fenos de alfafa e Tifton-85 e da silagem de milho. Semina: Ciências Agrárias, Londrina, v. 32, n. 2, p. 747-758, 2011.

LIMA, H. L.; GOES, R. H. T. B.; CERILO, S. L. N.; OLIVEIRA, E. R.; GRESSLER, M. G. M.; BRABES, K. C. S. Nutritional parameters of steers receiving different levels of sunflower crushed in partial replacement of soybean meal. Anais da Academia Brasileira de Ciências, Rio de Janeiro, v. 85, n. 4, p. 1513-1522, 2013.

MAURÍCIO, R. M.; MOULD, F. L.; DHANOA, M. S.; OWEN, E.; CHANNA, K. S.; THEODOROU, M. K. A semi-automated in vitro gas production technique for ruminant feedstuff evaluation. Animal Feed Science and Technology, Amsterdam, v. 79, n. 4, p. 321-330, 1999. 
MAURÍCIO, R. M.; PEREIRA, L. G. R.; GONÇALVES, L. C.; RODRIGUEZ, N. M. Relação entre pressão e volume para implantação da técnica in vitro semiautomática de produção de gases na avaliação de forrageiras tropicais. Arquivo Brasileiro de Medicina Veterinária e Zootecnia, Belo Horizonte, v. 55, n. 2, p. 1013-1020, 2003.

MEHREZ, A. Z.; $\square$ RSKOV, E. R.; McDONALD, I. Rates of rumen fermentation in relation to ammonia concentration. British Journal Nutrition, Cambridge, v. 38, n. 3, p. 437-443, 1977.

MENKE, K. H.; RAAB, L.; SALEWSKI, A.; STEINGASS, H.; FRITZ, D.; SCHNEIDER, W. The estimation of the digestibility and metabolizable energy content of ruminant feed-ingstuffs from the gas production when they are incubated with rumen liquor in vitro. Journal of Agricultural Science, Cambridge, v. 93, n. 1 , p. $217-222,1979$.

MESACASA, A. C.; ZERVOUDAKIS, J. T.; HATAMOTO-ZERVOUDAKIS, L. K.; CABRAL, L. S.; ABREU, J. G.; SILVA-MARQUES, R. P.; ALONSO, M. K.; SILVA, R. G. F.; SOARES, J. Q. Torta de girassol em suplementos múltiplos para bovinos em pastejo no período seco do ano: parâmetros nutricionais. Semina: Ciências Agrárias, Londrina, v. 36, n. 3, p. 1559-1570, 2015.

MIZUBUTI, I. Y.; RIBEIRO, E. L. A.; PEREIRA, E. S.; PINTO, A. P.; FRANCO, A. L. C.; SYPERRECK, M. A.; DÓREA, J. R. R.; CUNHA, G. E.; CAPELARI, G. M.; MUNIZ, E. B. Cinética de fermentação ruminal in vitro de alguns co-produtos gerados na cadeia produtiva do biodiesel pela técnica de produção de gás. Semina: Ciências Agrárias, Londrina, v. 32, n. 4, p. 2021-2028, 2011.

MORAES, E. H. B. K.; PAULINO, M. F.; VALADARES FILHO, S. C.; MORAES, K. A. K.; DETMANN, E.; SOUZA, M. G. Avaliação nutricional de estratégias de suplementação para bovinos de corte durante a estação da seca. Revista Brasileira de Zootecnia, Viçosa, MG, v. 39, n. 3, p. 608-616, 2010.

NEIVA JÚNIOR, A. P.; SILVA FILHO, J. C.; CLEEF, E. H.; PINTO, J. C.; ABDALLA, A. L.; TAVARES, V. B. Evaluation of elephant grass silages with forage radish, jatropha and lupine cakes as additives by the gas production technique. Ciência e Agrotecnologia, Lavras, v. 34, n. 4, p. 1024-1030, 2010.

PATRA, A. K. A meta-analysis of the effect of dietary fat on enteric methane production, digestibility and rumen fermentation in sheep, and a comparison of these responses between cattle and sheep. Livestock Science, Philadelphia, v. 162, p. 97-103, 2014.
PAULA, N. F. de; PAULINO, M. F.; COUTO, V. R. M.; DETMANN, E.; MACIEL, I. F. S.; VALENTE, É. E. L.; BARROS, L. V.; MENDES, R. K. V. Suplemento de baixo consumo para vacas de corte não-gestantes. Semina: Ciências Agrárias, Londrina, v. 35, n. 4, p. 1999-2010, 2014.

PIMENTEL, P. G.; REIS, R. B.; LEITE, L. A.; CAMPOS, W. E.; NEIVA, J. N. M.; SATURNINO, H. M.; COELHO, S. G. Parâmetros da fermentação ruminal e concentração de derivados de purina de vacas em lactação alimentadas com castanha de caju. Arquivo Brasileiro de Medicina Veterinária e Zootecnia, Belo Horizonte, v. 64, n. 4, p. 959-966, 2012.

PÔSSAS, F. P.; GONÇALVES, L. C.; PEREIRA, L. G. R.; MACHADO, F. S.; JAYME, D. G.; RODRIGUES, J. A. S.; RODRIGUEZ, N. M.; TOMICH, T. R. Cinética de fermentação ruminal das silagens de três híbridos de milho comerciais em diferentes estádios de maturação. Arquivo Brasileiro de Medicina Veterinária e Zootecnia, Belo Horizonte, v. 67, n. 1, p. 159-165, 2015.

RAMOS, A. F. O. Valor nutritivo da torta de castanha-dopará (Bertholletia excelsa Bonpl.) para alimentação de ruminantes. 2014. Dissertação (Mestrado em Zootecnia) - Universidade Federal do Pará, Belém.

RAMOS, A. F. O.; PINHO, B. D.; LOURENÇO JÚNIOR, J. B.; MACIEL E SILVA, A. G.; FATURI C.; MARTORANO, L. G.; MANNO, M. C.; LIMA, K. R. S.; SOUSA, L. F. Ingestive behavior of sheep fed Brazil nut cake in the diet. Semina: Ciências Agrárias, Londrina, v. 37, n. 4, p. 2259-2268, 2016.

REGAZZI, A. J.; SILVA, C. H. O. Teste para verificar a igualdade de parâmetros e a identidade de modelos de regressão não linear. I. Dados no delineamento inteiramente casualizado. Revista de Matemática e Estatística, Jaboticabal, v. 22, n. 3, p. 33-45, 2004.

REPORT of the protein group of the agricultural research council working party, on the nutrient of ruminants. London: Commonwealth Agricultural Bureaux, 1984. 45 p.

SANTOS, R. C.; ALVES, K. S.; MEZZOMO, R.; OLIVEIRA, L. R. S.; CUTRIM, D. O.; GOMES, D. I.; LEITE, G. P.; ARAUJO, Y. S. Performance of feedlot lambs fed palm kernel cake-based diets. Tropical Animal Health and Production, Berlin, v. 48, n. 2, p. 367-372, 2016.

SANTOS, V. C.; EZEQUIEL, J. M. B.; MORGADO, E. S.; HOMEM JÚNIOR, A. C.; FÁVARO, V. R.; D'AUREA, A. P.; SOUZA, S. F.; BARBOSA, J. C. Influência de subprodutos de oleaginosas sobre parâmetros ruminais e a degradação da matéria seca e da 
proteína bruta. Arquivo Brasileiro Medicina Veterinária e Zootecnia, Belo Horizonte, v. 64, n. 5, p. 1284-1291, 2012.

SATTER, L. D.; SLYTER, L. L. Effect of ammonia concentration on rumen microbial protein production in vitro. British Journal Nutrition, Cambridge, v. 32, n. 2, p. 199-208, 1974.

SILVA, D. J.; QUEIROZ, C. Análise de alimentos: métodos químicos e biológicos. Viçosa, MG: Universidade Federal de Viçosa, 2002. 235 p.

SOUSA, L. F.; MACEDO JUNIOR, G. L.; SANTOS, R. P.; SILVA, A. G. M.; BORGES, I. Composição bromatológica e cinética da fermentação ruminal de rações contendo resíduos de babaçu. Revista Ciência Agronômica, Fortaleza, v. 45, n. 1, p. 177-185, 2014.

SOUZA, M. L.; MENEZES, H. C. Processamentos de amêndoas e torta de castanha-do-brasil e farinha de mandioca: parâmetros de qualidade. Ciências $e$ Tecnologia de Alimentos, Campinas, v. 24, n. 1, p. 120128, 2004.

THEODOROU, M. K.; WILLIAMS, B. A.; DHANOA, M. S.; MCALLAN, A. B.; FRANCE, J. A simple gas production method using a pressure transducer to determine the fermentation kinetic of ruminant feeds. Animal Feed Science and Technology, Wageningen, v. 48, n. 3-4, p. 185-197, 1994.

VAN SOEST, P. J. Nutritional ecology of the ruminant. Ithaca: Cornell, 1994. 476 p.
VAN SOEST, P. J.; ROBERTSON, J. B.; LEWIS, B. A. Methods for dietary fiber, neutral detergent fiber, and nonstarch polysaccharides in relation to animal nutrition. Journal Dairy Science, Champaign, v. 74, n. 10, p. 35833597, 1991.

VARGAS, L. H.; LANA, R. P.; JHAM, G. N.; SANTOS, F. L.; QUEIROZ, A. C.; MANCIO, A. B. Adição de lipídios na ração de vacas leiteiras: parâmetros fermentativos ruminais, produção e composição do leite. Revista Brasileira de Zootecnia, Viçosa, MG, v. 31, n. 1, p. 522-529, 2002.

VIEIRA, P. F. Efeito do formaldeido na proteção de proteína e lipídeos em ração para ruminantes. 1980. Tese (Doutorado em Zootecnia) - Universidade Federal de Viçosa, Viçosa, MG.

WANG, L.; OISHI, K.; SATO, Y.; NAKANISHI, T.; HIROOKA, H.; TAKAHASHI, K.; KUMAGAI, H. In vitro ruminal fermentation and in situ ruminal degradation of tamarind kernel powder extract residue in wethers. Animal Science Journal, Kyoto, 2016.

WATANABE, Y.; SUZUKI, R. K. S.; NAGASHIMA, K.; MOCHIZUKI, M.; FORSTER, R. J.; KOBAYASHI, $\mathrm{Y}$. In vitro evaluation of cashew nut shell liquid as a methane-inhibiting and propionate-enhancing agent for ruminants. Journal Dairy Science, Hokkaido, v. 93, n. 11, p. 5258-67, 2010. 
